Article

\title{
Guidance as 'Women's Work': A New Generation of Female Islamic Authorities in Britain
}

\author{
Giulia Liberatore \\ Sociology and Islamic and Middle Eastern Studies, University of Edinburgh, Edinburgh EH8 9LD, UK; \\ giulia.liberatore@ed.ac.uk
}

Received: 17 August 2019; Accepted: 25 October 2019; Published: 30 October 2019

\begin{abstract}
This article is about a new publicly visible generation of female Islamic authorities in the UK and the ways in which they make sense of what it means to be a female authority within largely male-dominated structures of knowledge production. These authorities are setting up their own institutes and emphasising the importance of drawing from within the Islamic tradition while contextualising it in the British context. On the one hand, they stress their unique ability as women to provide personal and collective guidance, based on relationships of empathy and care, that addresses the needs of Muslim women in Britain. On the other hand, they recognise the limitations of presenting guidance as 'women's work', and they seek to pluralise their roles or to present gender as irrelevant in their work. By navigating between accepting, pluralising and transcending female modes of authority, they carve out legitimate spaces for themselves as female leaders while developing and imagining new understandings of Islamic knowledge and plural models of pious leadership. I argue that these multiple ways of making sense of their experiences move us away from theorising female religious leadership solely through binary tropes, such as liberal/orthodox Islam, resistance/compliance, enabling/constraining, which continue to shape research in the field.
\end{abstract}

Keywords: Islam in Britain; authority and leadership; Islamic knowledge; gender and piety; female Muslim authorities; Muslim subjectivities

\section{Introduction}

On 12 August 2016, I made my way from Oxford to North Wales, travelling over five hours through traffic and country roads to reach Glann Llyn, a 600-acre residential activity centre overlooking the beautiful, tranquil Lake Bala in North Wales, and the site of a four-day women's only retreat. Ustadha Iffet Rafeeq ${ }^{1}$ - a young female graduate of Jaamiat Al Karam, a Barelvi darul uloom (seminary) ${ }^{2}$ in Retford, Nottinghamshire, and founder of her own social media platform - had mentioned the retreat to me when we first met at the Cambridge Muslim College, where she was completing her diploma earlier that year. Advertised as an opportunity to 'rejuvenate' participants' spiritual and physical needs, the 'Beacon of Hope' retreat featured three UK-based female authorities delivering classes during the day, dhikr (remembrance) gatherings throughout the night, and a range of sporting activities in the company of roughly eighty young female professionals and students from across the country.

Throughout the retreat, Ustadha Iffet delivered several different classes featuring the lives of female saints and reflecting on how their experiences might relate to the lives of women in the UK.

1 Some interviewees asked me to use their real names, whereas others requested a pseudonym. For the small minority who

2 Al Karam is managed by Muhammad Imdad Hussain Pirzada, a Pakistani scholar of the Chisti Nizami Sufi order. 
Outside of the formal classes, she spent hours engaging in private conversations with the female participants. She barely had time for food, and one night, she spent hours helping one of the women attendees with a personal problem. As she explained to me when we spoke about her role as a female authority, 'You realise when you give a talk that after women come up to you with all sorts of problems, relationship problems, marriage, divorce, trauma ... very personal things, and you think, where is the support network? Why is no one addressing these issues?'

Ustadha Iffet is part of an emerging group of young female teachers and scholars in the UK. Over the last decade, the visibility of female Islamic authorities in Europe and globally has been growing (Bano and Kalmbach 2012; Kloos and Kunkler 2016; Hammer and Spielhaus 2013; Hill 2018). Lewis and Hamid (2018) described this emergence as one of the 'seismic changes' affecting British Islam and the wider Muslim World. In the UK, female authorities are a diverse group in terms of their age, traditional Islamic training, Islamic school of thought, secular education and ethnic and socio-economic background. This diversity is also reflected in the fragmented growth of new initiatives, institutes, and events on the topic of women, leadership and authority.

This article focuses on a new generation of publicly visible teachers and scholars who have been traditionally trained in the UK or abroad and are working from within the Islamic tradition while seeking innovative ways to apply it to the British context. It explores the ways in which these new authorities make sense of what it means to be a female authority within 'orthodox' structures of Islamic education (Asad 1986) and how, in the process, they develop new forms of knowledge and ideals of pious leadership.

Many of these new female authorities present themselves as naturally able to empathise, nurture and care, while adapting knowledge to suit individual circumstances and local community needs. While engaged in diverse teaching, preaching and scholarly activities-as highlighted by the vignette above - many of these young authorities spend a vast amount of their time offering individual or collective advice and guidance to Muslim women on issues ranging from marriage and divorce to mental health, spirituality, faith and Islamic practice. On the one hand, they present guidance as 'women's work', that is, as an area of Islamic knowledge in which women have particular expertise and which complements rather than competes with men's work. They see themselves as fulfilling a need among Muslim women—as Ustadha Iffet's comment above suggests—as well as fulfilling the expectations of their communities, who see them as 'natural guides'. On the other hand, they recognise the irrelevance of gender in matters of faith and spirituality or seek to pluralise ideals of Islamic female leadership.

By navigating between these different positions, these authorities are carving out legitimate and relatively uncontroversial spaces for themselves while also developing and imagining new forms of knowledge and ideals of pious female leadership. Building on recent work on the ethical imagination (Moore 2011) and on my own research on gender and Muslim women's multiple and complex subjectivities (Liberatore 2017; see also Sehlikoglu 2018, forthcoming), I point to the ways in which navigating between these different forms of knowledge can involve new processes of imagination and ethical self-making. In doing so, I bring to the fore the multiple, overlapping and fluid ways in which these emerging Islamic authorities navigate structures of knowledge and make sense of themselves as leaders. Drawing on Stewart's notion of 'weak theory', I suggest that this multiplicity and fluidity of subjectivities means that they can never be fully captured by 'strong' theoretical frameworks, binaries or the linear arguments of academic debate. Stewart (2008, p. 72) experiments with 'theory that comes unstuck from its own line of thought to follow the objects it encounters, or becomes undone by its attention to things that don't just add up but take on a life of their own as problems for thought.' Only a weak theory can account for these moments, she elaborates, because it does not seek to 'judge the value of an analytic object or to somehow get their representation "right"', but rather 'wonders where they might go and what potential modes of knowing, relating, and attending to things are already somehow present in them as a potential or resonance' (ibid. 2008, p. 73). I suggest that the work of female authorities risks being flattened by academic studies or public discussions on Muslim 
subjectivities that are organised around binary tropes such as liberal/orthodox, enabling/constraining or resistance/compliance.

\section{Methods}

This article draws on a larger ethnographic research project on female Islamic authority and guidance in the UK that I conducted between April 2015 and October 2019. The research involved mapping a broad range of female authorities across the country, analysing their online presence, interviewing over twenty-five female Islamic authorities (scholars, teachers, preachers, as well as authorities providing legal advice or counseling), visiting spaces of learning, attending classes and retreats, speaking to audience members and discussing the topic with male Islamic authorities and other experts in the area. ${ }^{3}$ Interviews with female authorities were semi-structured and focused loosely around the following themes: education and training; journeys to scholarship/teaching/preaching; opportunities and constraints experienced in education and work; current work; content and style of any teaching and preaching; ideas about Islamic authority and leadership; Islamic knowledge production and dissemination; engagements with civil society, government or other organisations. While I introduced these topics at various points throughout the interviews, I allowed participants to shape their own narratives wherever possible in order to explore how they wanted to narrate their personal trajectories and to describe the work that they do. Most of the female authorities I interviewed were recruited through personal contacts and networks, and some were contacted via email or through social media platforms. In addition, I spent many hours attending classes, lectures and retreats organised by these authorities, following their engagement on social media and participating in online classes and sermons. Through my involvement in these activities, I was able to build close relationships of trust and friendship over the years.

The following discussion focuses on one of the questions explored during this research: How do female leaders make sense of their female authority? It is based on participant observation and interviews conducted with a sub-group of ten newly emerging female teachers and scholars with traditional training in the Islamic Sciences. This more recent generation is rapidly expanding, and their experiences reveal developing patterns and changes in the fields of Islamic knowledge and gender. Throughout, I prioritise the narrative accounts of female authorities and the ways in which they understand their own authority and gendered subjectivities. Drawing on feminist epistemologies, I treat my interlocutors as theorists and co-producers of knowledge rather than as the subjects of research (see Liberatore 2017, chp. 2). ${ }^{4}$ By juxtaposing their voices and experiences, I explore different perspectives on female authority, bringing out emerging patterns, convergences and contradictions. I also include some of the voices of female audience members and male scholars with whom I discussed the topic. The article also builds on long-term fieldwork with Muslim communities (ibid. 2017) during which I first encountered the work of UK-based female scholars.

The following section (Section 2) introduces this new but highly diverse generation of female authorities and accounts for their recent emergence in the UK, exploring how they make sense of the opportunities and constraints they encounter through their work. Sections 3 and 4 move away from an analysis of opportunities and constraints to explore the multiple ways in which these female authorities make sense of their work by presenting themselves as 'natural guides' while, at the same time, recognising and critiquing some of the limitations of doing so and pluralising or transcending these ideals. Section 5 situates the rise of these new female Islamic authorities among global, regional and local shifts in Islamic knowledge and highlights this article's engagements with the field of Islamic

3 I use the term 'authorities' mostly to talk about women who self-define as teachers, scholars or preachers and who have received some traditional training in the UK or abroad.

4 The female authorities who participated in the project were sent a draft of this article prior to publication. Some replied with suggestions and/or amendments which have been incorporated into the final draft. 
knowledge production and female leadership. The article concludes with a reflection on how these female authorities are shaping knowledge production and notions of leadership and authority.

\section{New Female Islamic Authorities in Britain}

The new generation of Islamic authorities discussed in this article are mostly women whose parents or grandparents settled in the UK from South Asia or, in smaller numbers, from North Africa and the Middle East. Within this diverse group is a small cohort of slightly older but more authoritative women who completed most of their training abroad, in the Middle East. Shaykha Safia Shahid, for example, was born and raised in Glasgow and moved to Syria for five years in 2003, where she studied Arabic at the University of Damascus and earned several ijaza (licenses to teach) with scholars such as the Shadhili Shaykh Muhammad al-Yaqoubi. She is currently completing an MRes in Islamic Studies in the UK. Similarly, Ustadha Nagebah Hayel Muckbel studied Arabic at the University of Damascus and tajweed (Quranic recitation) with the Damascus-based female scholar al-Haja al-Najah for several years. She then moved to Tarim, Yemen where she completed the four-year programme at the female madrasa al-Zahra, where she later taught figh (jurisprudence), aqeedah (creed) and Arabic grammar.

The younger women, who are in their 20s and 30s, are more numerous and have been predominantly trained in the UK, in either the Barelvi or Deobandi institutions. Many have also encountered teachings from other schools of thought that are present in the UK and, in some cases, have incorporated parts of these into their work. Of the ten authorities interviewed, four had trained at an Islamic seminary and had combined their studies with an undergraduate or postgraduate degree or diploma at a British university. For example, Ustadha Iffet, like her fellow Islamic authority Ustadha Noor, had attended the Jaamiat Al Karam. She subsequently spent a year perfecting her Arabic in Egypt ${ }^{5}$ but was forced to return to England in 2011 and enrolled on the Diploma in Contextual Islamic Studies \& Leadership at the Cambridge Muslim College (CMC). Another young authority, Ustadha Khadijah, had enrolled in a part-time alimah (scholar) course with a Deobandi educational institute while finishing her secondary school studies in the early 2000s. ${ }^{6}$ She then travelled to Jordan with her husband to study under Shaykh Nuh Keller, an American convert and the head of the Shadhili order. On returning to the UK, she enrolled on the diploma at Cambridge Muslim College (a year before Ustadha Iffet and Noor) and completed a Masters' at a London-based university. Ustadha Aliya, however, had followed a less linear path to scholarship. She studied Arabic at university in the UK and then travelled to Egypt for a year, to Damascus and Tarim for a few months, and to Morocco for a year, receiving several ijaza in tajweed and hadith in these various locations. Once she returned to the UK, she enrolled at Cambridge Muslim College, and later completed an MSc in Education while studying for an alimah course part-time.

The ways in which differences between the older and younger cohorts overlap with educational opportunities are partly due to the difficulties surrounding studying in the Middle East since the 2011 revolutions, coupled with the opening up of more opportunities for young women to complete their traditional studies in the UK. These different experiences have also led to divergences between schools of thought, with the younger generations trained in Islamic schools that originated in the South Asian sub-continent and that are dominant in the UK because of historic migration and settlement patterns (Bowen 2016). This has also meant that these younger authorities engage with slightly different audiences and communities than their older colleagues and that their experiences of opportunities and constraints are specific to them and not necessarily generalisable across all female authorities. Given the diversity of their scholarly backgrounds, these new female authorities do not form a cohesive

5 The Al Karam seminary has well established connections with Al Azhar, where if often sends its graduates for further study. 6 The institute was one of the first in the UK to offer this programme to women part-time. Ustadha Khadijah, however, mentioned that her part-time alimah course was considered within scholarly circles as less authoritative than full-time courses delivered in boarding schools. 
group, and the women do not necessarily know each other, although they may have heard of each other or been invited to speak at the same events and retreats.

Despite their differences, both sub-groups of this new generation of female authorities differentiate themselves from the much older generation, who tend to be first-generation migrants who teach in Urdu or in languages other than English and focus predominantly on delivering Quranic recitation classes to young children or to small private circles of women. By contrast, the new generation is more publicly visible; its female authorities are setting up their own institutes and are teaching adults as well as children a range of different topics in English. They are distancing themselves from the sectarian Islamic identities (Deobandi/Barelvi) of previous generations and moving towards forms of knowledge that address a broader British Muslim audience. ${ }^{7}$ As Ustadha Iffet summarised in an interview in 2016, 'before it was really about intimate, private circles ... the wives of Shaykhs or young scholars holding meetings in homes or prayer rooms. But over the last five or six years some of us have started to go public.' These new female Islamic authorities are shifting between different modes of establishing authority (Bano and Kalmbach 2012; Kloos and Kunkler 2016) as they navigate between working in formal roles within existing Islamic institutes and teaching in informal spaces or setting up their own organisations, and thus engaging with new audiences.

While some have embraced social media in order to engage with a more diverse national audience, others have a limited presence online and focus instead on working with local audiences. ${ }^{8}$ For example, Shaykha Safia Shahid, with the support of Shaykh al-Yaqoubi, became the Principal of the Women's Muslim College (WMC) in 2017, an organisation that offers certificates, a diploma and a four-year programme in the 'Islamic Sciences in a Modern Context' online and in a range of locations across the UK. It also organises an annual retreat. ${ }^{9}$ The Shaykha is active on social media, where she promotes the work of the College and advertises her events and classes. Her public visibility means that she is very often invited to deliver talks at universities and Muslim and non-Muslim organisations across the globe. Ustadha Iffet is similarly active online. In 2012, she set up 'Dust to Diamonds', a social media platform (available on Facebook, Snapchat, Twitter and Youtube) where she regularly engages in exchanges with her followers and posts advice, quotations from the Quran or hadith or by famous scholars, and information on events. She also regularly tours the UK delivering lectures.

In contrast, Ustadha Khadijah has almost no presence online and works predominantly with her local community in east London. In 2008, she set up her own institute, which now delivers courses on topics ranging from Arabic to Ramadan preparation and holistic health, and occasionally runs tai chi classes or Arabic language toddler groups. Ustadha Khadijah also teaches Arabic and works as a chaplain in an Islamic institute in London, all while caring for her young children. Ustadha Salma, another young authority and darul uloom graduate, is the only authority working formally in a mosque where she runs regular sessions for women and young girls.

In contrast to the first generation of teachers, the legitimacy of these new female authorities is tied not to their husbands or fathers, but to the level and depth of their own scholarship and to their reputation for personal piety. Many have trained alongside their husbands-sometimes enrolling in the same institutions and programmes—and the couple mutually advise and support each other. The depth of the women's scholarship, however, is often assessed according to where and with whom they have studied. Studying in a renowned seminary like, Al-Karam, or receiving an ijaza under a famous male scholar (e.g., Shaykh al-Yaqoubi) is important for the women's futures, as they benefit from the support of the scholars as referees and promoters of their work. These referees act as hosts, 'inviting' female authorities to teach in mosques and other male-dominated Islamic institutions (Kalmbach

\footnotetext{
This is also reflected in the use of titles such as Ustadha or Shaykha rather than alimah or $\bar{a} p \bar{a}$ (big sister) in Urdu. Most are assigned the title Ustadha, but out of modesty, they hardly ever claim it themselves.

While the Women's Muslim College is only for women, Shaykha Safia Shahid is one of the only female scholars in the UK to openly lecture both men and women. Most other female authorities prefer to operate in gender-segregated environments and never or only very occasionally deliver talks in mixed settings.
} 
2012). Therefore, while these new female authorities are creating their own spaces and initiatives, their legitimacy is tied in complex ways to that of male scholars, who often dominate the management or boards of mosques and Islamic institutions, and the audiences and communities with whom they engage. Ustadha Noor, for example, greatly benefits from the networks she established while at Al-Karam, as well as from the connections of her father-in-law, a well-respected imam in her local Barelvi community, in attracting students to her classes and receiving invitations to speak across the country.

Some younger female authorities, however, described the frustrating ways in which they continue to be seen by their communities as less authoritative than their male counterparts. As Ustadha Iffet put it, 'scholarship in the UK has been restricted to a male-dominated field and it really feels that we're imposing ourselves'. As mentioned, the large majority of British Muslims have roots in the Indian subcontinent and have brought with them traditions of Islam-in which some of these younger scholars are immersed-that tend to be more restrictive in terms of women's involvement in public affairs. In voicing these critiques, these young authorities often employed a discourse of 'religion versus culture', suggesting that 'cultural norms and practices' were constraining their work in contradiction of an authentic Islam that empowers and encourages women to study and to engage in the public sphere (Ewing 2008). When Ustadha Khadijah first started delivering talks within her local Deobandi community in the mid-2000s, she was forced to conceal her identity by using Ustadha 'bint Muhammad' (daughter of Muhammad) on posters advertising her talks, an attempt at using her name having sparked controversy. She also described the ways in which she had to gain the trust of the local imams and male scholars in her area before she could start delivering classes to women and carving out greater spaces for women in her local mosque. Ustadha Noor also commented on the difficulties of being remunerated fairly for her work when compared to male scholars. She felt that students did not take her seriously as a scholar and did not appreciate the effort, time and money she had invested in her education or the research that she undertook when advising on a particular issue.

Those who have studied in seminaries within the UK are also often seen as less authoritative than those who have studied abroad for long periods of time but also less knowledgeable than male counterparts who studied at the same seminaries. This is because, with the exception of Al Karam, the curriculum for women is considered shorter and less rigorous than that offered to men at the same seminaries (Scott-Baumann and Cheruvallil-Contractor 2015, p. 121). ${ }^{10}$ As a male scholar I interviewed told me, 'until the education they [female scholars] receive is on a par with that of men, they will always be seen as inferior scholars.' Furthermore, studying in major institutions abroad is not only increasingly difficult but is only available to a small minority of women.

For some of this younger generation trained in the UK, legitimacy within their local communities has not only depended on the level and depth of their scholarship, but also on their carefully negotiating their way within existing structures of authority. Other female scholars, however, claim that they have never felt constrained in their work. As Shaykha Safia Shahid elaborated in an interview, 'male scholars have invited me to events and talks.' She claims never to have felt that she was treated differently as a female scholar, and my question on this issue surprised her as she did not find it relevant to her own experiences. ${ }^{11}$ Her remarks were echoed by Ustadha Nagebah, who similarly, felt that she had never experienced barriers or limitations in her learning and teaching. ${ }^{12}$ As I elaborate in more detail below, the only barrier she spoke about in relation to her work was a lack of support networks available in an individualistic society such as the UK. While not all female authorities shared this view, nonetheless,

10 Female scholars who had been to Al Karam reported that teaching now occurs alongside men, with the same male teacher addressing both male and female audiences separated by a large screen.

11 This may due to her high status as well as the particular nature of the communities in Birmingham and London with which she engages, which are more accepting of female scholarship.

12 The female audiences in Liverpool are incredibly diverse, Ustadha Nagebah explained, and less influenced by schools of thought originating in South Asia, which may be why she has experienced fewer obstacles in her work. 
none engaged with a liberal discourse of empowerment or spoke about resisting patriarchal forms of authority. Furthermore, most emphasised that their main concern was not resistance (or compliance) but rather, as I expand on in the next section, to provide guidance and pious leadership to Muslim women who approached them for help.

\section{Women as Guides}

\subsection{Guidance as Women's Expertise}

Female authorities teach a broad range of different topics within their institutes or other Islamic organisations, from tajweed (Quranic recitation), to tasawuuf (spirituality) and figh (jurisprudence). When questioned about the work that they do, however, many new female authorities across the different schools of thought stressed the importance of 'providing guidance' for Muslim women in the UK, and several emphasised that guidance was an area of female expertise. As the following examples demonstrate, guidance involves drawing on different forms of knowledge, ranging from figh to spiritual guidance and counseling support in one-to-one or group sessions.

Advising on marriage and relationships was something Ustadha Iffet found herself having to do on a weekly basis. Consequently, she realised that there was a need to provide advice to larger groups of young women. Her social media platform, Dust to Diamonds, which has over ten thousand subscribers, enables her to do just that, providing, in her words, 'the way to reach so many different kinds of people globally'. The majority of her time is spent answering questions that she receives from her subscribers and preparing YouTube videos that respond directly to their concerns. In her videos, she is not scared to address some of the most 'thorny and taboo' issues of the day: 'these things are normally hidden', she explains in a video on haram relationships. Her YouTube videos are short, typically lasting between five and ten minutes, and each addresses an everyday problem on which she feels her listeners need guidance. Subjects and titles include marriage, study, friendship, love, '4 tips for student life', 'getting married or die trying', 'food and soul', 'suffering from anxiety' and 'how to spend holidays like a Muslim'. She takes on the role of a teacher or preacher, but she speaks directly to her listeners, addressing them personally. While she is funny and entertaining, the moral lessons she imparts are conveyed with seriousness and authority, as she cites Islamic sources and alters her tone to reflect this. Her short talks often follow a similar structure: a question or problem is identified at the start (e.g., women's personal insecurities); this is unpacked and the reasons or causes underlying this issue explored (e.g., the role of media in defining beauty and making us feel imperfect). This is usually followed by a critique or admonishment (e.g., the media is not real, you shouldn't let it shape who you are), and a resolution is offered at the end, which most often involves returning to Allah or seeking His help (e.g., Allah has defined us as beautiful; what matters is your personality and actions, what's inside in your hearts). Her videos are carefully edited and as she talks, words or hashtags flash on the screen along with diagrams and images used to illustrate her points. She also occasionally draws on her own experiences (e.g., her own insecurities or mistakes). Her talks often end with 'I am here for you' (addressed to sisters who may need her help), a reminder of her email address, and requests for $d u a$ (prayers or supplications) and for her listeners to act as her witnesses on the Day of Judgment.

In her work at her own east London institute, Ustadha Khadijah is similarly concerned with offering guidance, albeit in a very different setting. During my research, I attended several of her courses and I always did my best to arrive early so as not to miss the first fifteen minutes of the class. Ustadha Khadijah would enter the class, sit at the teacher's desk, lift her niqab and greet us individually, asking each of us about our week. She would then share her own thoughts and experiences of the week, while connecting these with Islamic sources. She might speak about her experience training as a hypnobirthing teacher, impart breastfeeding advice, discuss the importance of keeping children away from screens and devices or talk about the importance of caring and engaging with multiple others, including non-Muslims. She often referred us back to the Quran as a 'book of guidance', as a text that we could turn to for any sort of advice, support, and personal and collective guidance. This was a very 
special moment of intimacy where we could ask questions and seek advice, but also listen and learn through her personal experiences.

As Ustadha Iffet and Ustadha Khadijah's experiences demonstrate, many young Muslims in Britain are in need of personal spiritual and moral guidance. They often find that their parents are unable to provide the support that they need, as their understanding of the British context is limited and their knowledge of their faith is considered—by their children — to be 'cultural' and insufficiently Islamic. School and university teachers or counselors are also considered to know little about Islam and these young people's cultural backgrounds. Research has shown how young Muslims seek support in adapting a virtuous Islamic life to a non-Muslim, Western, secular context, and revealed that they need religious authorities to help them to engage in 'Islamically correct' behaviour (Jouili and Amir-Moazami 2006, p. 636; see also Jouili 2015).

Ustadha Noor found that when she was approached by Muslim women for advice, they most often asked not for figh advice or for a fatwa (non-binding legal judgement) but 'for what is good and moral for them'. She felt she could not refer them elsewhere, as there was no one else in the community with whom they could or would be willing to talk. Similarly, Ustadha Salma explained in an interview: 'It's not possible for women to go to an imam for everything, and imams have lots of other things to do ...' ' In the mosque she provides counseling and guidance to women in the community and organises talks on topics she is often asked about by the community (e.g., marriage or the challenges of educating Muslim children in Britain). She has also recently started working as a chaplain in a local hospital. While male scholars and imams do engage in guidance work, as Ustadha Salma suggested, they are often involved in other activities, such as providing teaching, issuing fatwas, leading prayer or delivering Friday sermons, which are traditionally viewed as men's area of authority. For female authorities, therefore, guidance is seen as complementing but not competing with the work that men already do. In the UK, chaplaincy and counselor roles are also increasingly providing opportunities for formal and paid employment for traditionally trained male and female Islamic scholars (Gilliat-Ray et al. 2013). Women are beginning to take advantage of these opportunities: two out of the ten female authorities I interviewed were employed part-time as chaplains in various institutions.

\subsection{Guidance as a Female Mode of Teaching}

As the examples above suggest, guidance work can involve discussing controversial, 'thorny and taboo' subjects, or 'female topics' — such as childcare and menstruation-that are regarded as too personal or intimate to discuss with a male scholar. However, in several of my discussions with female authorities, they also presented guidance as an extension of women's natural skills; many pointed less to the content of the guidance they provided and more to their mode of engaging with students. This was also evident in Ustadha Iffet and Ustadha Khadijah's classes (described above), where the relationship between scholar and audience was based on intimacy, empathy and care and was central to their work. Female authorities claimed that women are naturally caring, compassionate, loving, merciful and more understanding of individual needs, and are particularly skilled at adapting knowledge to different circumstances and contexts. These female characteristics were used to account for, what they deemed to be, distinctly female forms of knowledge and authority. Based on a conception of gender as rooted in biology, these women supported these positions by drawing on examples from within the Islamic tradition.

Ustadha Noor emphasised how female scholars had 'a special aura' about them that men lacked and that enabled them to 'build connections' with their female students. When we met in the summer of 2019, she described a course she had taught alongside her husband in the same mosque. They had prepared the content of the course together, but she had delivered it to women and he had addressed the men. At the end of the session, her female listeners, who had never been taught by a woman before, told her that her sessions were different: 'thank you for making us feel we can approach you, for being so open, we can talk to you on a normal level and there isn't that formality', they told her. As she narrated the incident, Ustadha Noor elaborated: 'it's because of that motherly nature that we have'. 
As an Islamic teacher, it was important for her to empathise with her students and to care for them: 'women are great at making people feel good, making them feel at home so when we speak to them, we open the doors of our hearts to them'.

The idea of naturally female characteristics being the basis for female authority was also furthered by Ustadha Nagebah, who explained to me: 'Women's brains are wired in particular ways. While men might have a spot in their brain for compassion, we have several ... ' She explained how many people came to her and her husband for help with difficult situations and problems. She told me that while her husband feels 'sadness, and does his best to help ... he can then put it aside', she struggles and carries 'the sadness ... for days.' These notions of women being naturally caring are often accompanied references to female role models who exemplify 'mothering' and 'caring' characteristics, such as Khadijah, the first wife of the Prophet, or Maryam the mother of Jesus. Indeed, reflecting Cheruvallil-Contractor's (2016, p. 15) analysis of the Islamic texts, many female authorities stress 'the special status given to mothers', and the value Islam places on motherhood, particularly in the hadith literature (Cheruvallil-Contractor 2016, p. 15).

In claiming guidance as female expertise, some female authorities emphasised not only naturally acquired skills, but also experiential notions of gender. Ustadha Khadijah recognised the shared experience of motherhood, explaining that, as mothers, wives, sisters and daughters, women shared similar life experiences and could use these in imparting knowledge. Similarly to other female authorities, she would often use examples from women's shared experiences, such as child birth or raising and educating children, to illustrate her teachings. She also noted how the experience of managing multiple roles and adapting to changes while responding to the needs of the family had taught her about the importance of contextualising and adjusting knowledge to the different experiences of individuals and communities. 'With women we spend a lot more time with our children, we understand the needs of the community better because we see our very own children going through the challenges. We have to adjust, we can't be textbook or theory based all the time', she elaborated.

My discussions with audience members at women-only classes or gatherings reinforced the sentiments expressed by these female authorities. Many participants noted how these settings were different, more relaxed and intimate than those led by a male scholar. Some explained how they could ask 'intimate' questions that they might not be comfortable discussing with a male scholar. ${ }^{13}$ While their decision to follow a particular scholar was based on their depth and range of knowledge-regardless of gender-the women preferred a female scholar with equal knowledge. 'They [female scholars] understand where I'm coming from .... they connect with you differently ... and I can ask her things a male scholar wouldn't get', a young female audience member told me at a women-only retreat one summer.

\subsection{New Imaginings of Pious Leadership}

For female authorities in the UK, the processes of nurturing and caring are spiritual, experiential and affective, as highlighted by Ustadha Noor and Ustadha Nagebah. But they also involve reasoning, problem solving, application and contextualising. The process of offering practical advice through intimate, empathic and less hierarchical relationships between teacher and student is presented as a distinctly female mode of authority that, as I elaborate in the conclusion, points to the expansion of new understandings of Islamic knowledge that cater to the needs of Muslims in Europe.

In many ways, the experiences of female Islamic authorities in the UK resemble those of the muqaddamas (female spiritual guides) of the Fayḍa Tijāniyya Sufi Islamic movement in Dakar, Senegal, as described by Hill (2018). Muqaddamas present spiritual guidance as a natural extension of motherhood, turn devotional cooking into a form of prestige, and perform wifely obedience, shyness and modesty

13 In her study of al-Qubaysiyyat in Syria, Omar (2013, p. 362) similarly notes how students seek approval and advice on very personal decisions from their female teachers, which they would not feel comfortable addressing with male scholars. 
as acts of 'self-wrapping'. Just as muqaddamas draw on norms of feminine piety to carve out legitimate spaces of authority, emerging female authorities in the UK are establishing legitimacy by developing distinctive areas of expertise through both the content and style of their teaching. They are addressing a growing need in their communities but doing so without contravening dominant understandings of gender segregation and orthodox norms of piety that naturalise women's roles as mothers and carers.

Moreover, guidance for many of these female authorities is not restricted to the individual. Drawing on their work with pious women in France and Germany, Jouili and Amir-Moazami (2006, p. 622) discuss the importance attributed to motherhood in the Muslim community and society at large. Within this conception of motherhood-which emerged in the Ottoman Empire in the second half of the nineteenth century-the domestic sphere is not 'constitutive of processes of individualisation' but is rather 'a space that is largely societal and political' (ibid. 2006, p. 623). In a similar way, female authorities who emphasise guidance as women's natural area of expertise, view their nurturing work as providing more than just individual advice; they see it as guiding the Muslim community, and developing and imagining new models of pious female leadership. Ustadha Nagebah, echoing the sentiments of several other authorities, emphasised how she deliberately chose to spend time 'building a community' rather than touring or travelling to deliver lectures and classes. She stressed the role played by female scholars in community-building: by working with the disadvantaged, caring for nature and the environment, and nurturing the potential of very young children, they were sowing the seeds of a future community. Inspired by Prophetic values, these communities, which placed women at their core, could draw on Islamic frameworks to offer an alternative to-what they perceived as-the problems of 'Western' society, including individualism and the absence of family and societal networks of support. Ustadha Nagebah suggested that the social context in the UK did not facilitate female scholarship, as it was built around the individual instead of being organised in support of a community. Islam, by contrast, offered a model that not only valued motherhood, but also provided societal support for women to engage in the public sphere as leaders in their communities.

\section{Beyond Guidance: Transcending and Pluralising Gender}

While Ustadha Nagebah stressed the unique way in which female scholars were able to guide and connect with their female students, she simultaneously held the seemingly contradictory view that gender was insignificant in her teaching: 'when teaching jurisprudence, theology, the Arabic language... the law is the law, it is absolutely insignificant as to what gender you receive the law from'. The practice of Islam, she explained, is a 'human experience' and therefore constrained within the earthly realm; Islamic knowledge, on the other hand, is based on the unity of the divine. Hill (2018) similarly describes the ways in which muqaddamas are able to hold paradoxical truths simultaneously by treating gender distinctions as an apparent (zahir) truth and absolute equality between genders as a hidden truth (batin). At the same time as performing feminine piety through acts of obedience and self-wrapping, muqaddamas employ mystical discourses to describe themselves as 'spiritual men' or to transcend gender distinctions altogether through unity with a genderless God.

In a similar fashion, Shaykha Safia Shahid preferred not to emphasise her gendered authority in presenting herself as a scholar. While she stressed the importance of 'female empowerment' through her work training a generation of young female scholars at the Women's Muslim College, she also told me that she viewed 'gender as irrelevant'. In her college, women taught and learnt traditional subjects to the same level as those taught in male-led institutions. She also pointed to the diversity of classes and courses she had delivered on a range of different topics. Women might have different experiences, she explained, and 'there are insights that women can offer, for example, about raising children, childbirth, marriage', but when it came to issues of spirituality, Islamic knowledge and scholarship, there was no difference between men and women, she clarified, drawing from the Sufi tradition that emphasises the 'ontological equality of man and woman in the Quran' (Spielhaus 2012). She pointed to Aisha, the Prophet's wife, whom she claimed was a great scholar and transmitter of knowledge: 'Most illustrious male companions of the Prophet (peace be upon him) used to ask for her advice and her counsel', she 
explained, emphasising the ways in which gender could be transcended in scholarly and spiritual pursuits and did not need to be constraining.

In elevating Aisha as a scholar, Shaykha Safia Shahid was not only transcending gender distinctions but seeking to pluralise the tradition from within. Other female authorities, such as Ustadha Iffet, were similarly involved in this struggle to move beyond monolithic models of pious leadership. When I met Ustadha Iffet in Birmingham in early 2019, a few years after the summer retreat, she had grown increasingly frustrated with the restrictive roles assigned to female scholars. She felt that guidance was being relegated to a lesser form of authority and that her work was being downplayed. She suggested that event organisers and audience members were requesting that she and other female authorities provide 'nurturing discussions, to provide spiritual highs, to be an emotional outlet', and were encouraging her to develop a style of teaching that was more 'emotional' than 'academic.' She explained, 'women in the audience don't want to hear my intellectual reasoning on an issue, my explanation of the different legal opinions, they don't want to know that kind of knowledge.' She had also been targeted and criticised for her online presence and her self-presentation: as someone who regularly wears a hijab, a nose piercing and make-up, she has been criticised for being 'liberal', insufficiently modest, and 'overly sexualised'.

In our conversation, she insisted that the Islamic tradition offered many female role models and did not narrowly circumscribe Muslim femininity. She suggested that Aisha, the wife of the Prophet, 'never had children' and 'didn't have that soft, motherly role. She was academic in her approach'. Similarly, while Maryam, the mother of Jesus, was loving and nurturing, she was also 'hard and powerful.' 'Her labour is described in the Quran as really difficult and she endures it with patience', Ustadha Iffet told me. A focus on 'motherly' topics, she felt, was excluding to women who were not mothers or who had no desire to be mothers. She also felt that it forced women to conform to one mode of femininity and to emphasise their emotional rather than intellectual qualities.

According to Ustadha Iffet, it was important to pluralise the tradition and recover a wide range of female pious public figures who were more than just mothers. Her comments echo Cheruvallil-Contractor's (2016, p. 17) observation that within Islamic seminaries and institutions in the UK, some of which rely too heavily on the reformist texts of Thanvi and Maududi, motherhood is 'over-signified'. Through a critical reading of the texts, Cheruvallil-Contractor argues that the Islamic tradition is relatively silent on the necessity of being a mother, what motherhood entails, and its ties to domesticity. Ustadha Iffet similarly problematises the naturalisation of motherhood and the narrowing of women's experiences to the role of wife and mother while also pluralising women's roles and recognising that the Islamic tradition is replete with examples of women who were not 'just mothers' (ibid. 2016, p. 15). She is drawing inspiration from feminist critiques of male-dominated Muslim communities but weaving these back into the tradition. Through her own work and self-presentation, she also seeks to pluralise imaginings of female Islamic leadership without resorting to binaries of liberalism/orthodox Islam or resistance/submission. However, as she confessed to me that afternoon when we met in Birmingham, she is also paying a price for it.

\section{Islam, Gender and Leadership}

The recent emergence of female Islamic authorities in the UK has been shaped by global, regional and national changes in Islamic knowledge production, as well as discourses around gender and Islam. Over the last couple of decades, we have witnessed the greater involvement of women in Islamic education initiatives and piety movements across the globe, as Muslim women from a range of different socio-economic backgrounds have sought Islamic knowledge with the aim of leading more ethical lives (Mahmood 2005; Deeb 2006; Bano 2017). This has led to the emergence or, in some contexts, the re-emergence or expansion of female-only study circles and classes and relatedly, to the 'feminisation of religious authority' (Jouili and Amir-Moazami 2006).

This trend has been accompanied by global discourses on gender equality, women's rights and female empowerment that have generated greater public debate about Muslim women and leadership. 
In the UK, the rhetoric of 'female empowerment' and 'gender equality' is often at the forefront of public discourses, media accounts or policy interventions that celebrate the inclusion of Muslim women as a sign that Islam is becoming more democratic and liberal and therefore, more 'British'. While the authorities discussed in this article do not employ these liberal discourses, the proliferation of these debates and the related rise of Islamic feminism have nonetheless encouraged greater public awareness and debate about female leadership within Islam. Indeed, as I have shown, while female authorities distance themselves from the binary of liberalism vs. orthodox Islam, it continues to be propagated not only through public discourses but also by mainstream Muslim communities, and thus impacts in significant ways on the experiences and claims to legitimacy of female authorities.

This liberal vs. conservative or orthodox trope also often shapes scholarly debates on female leadership. A large body of work has developed around progressive spaces and feminist scholarship, re-interpretation and argumentation (Hammer and Spielhaus 2013; Mir-Hosseini et al. 2015; Petersen 2019). Often, the latter are juxtaposed to conservative, traditional or orthodox ones, but they are also disproportionately represented in the scholarship and policy relative to the percentage of individuals involved in these movements. In Europe, the liberal/conservative or orthodox binary has also played out in public discourse through the ways in which female leadership has been tied to particular opportunities and constraints or enabling and constraining circumstances. For example, a liberalising context is often seen as having enabled the recent rise of female leaders through its values of equality and emancipation and the educational opportunities, spaces, resources and employment opportunities provided for women. In contrast, conservative or patriarchal cultural-religious norms and practices, families and communities are viewed as constraints or impediments to their public engagement. As a consequence, Muslim women are too often portrayed as the objects of male-dominant religio-cultural systems (Ewing 2008) and are positioned as either resisting or accommodating patriarchal norms and practices.

Recent scholarly work has sought to move beyond this liberal/orthodox divide (Bano and Kalmbach 2012; Kloos and Kunkler 2016). In the first significant edited volume on the topic, Bano and Kalmbach (2012) highlighted the varied and expanding work of female Islamic authorities in formal institutions and mosques thanks to growing educational and employment opportunities and broader shifts in Islamic authority and the roles and activities of women in Muslim contexts. Building on this research, Kloos and Kunkler (2016) pointed to the ways in which female leaders operate out of informal, relatively unregulated institutions and settings that allows them to compete with male dominated religious establishments' (ibid. 2016, p. 487). By focusing on the importance of 'communities' and the ways in which they react to female religious leaders, the authors expand on Bano and Kalmbach's (2012) tripartite model, which identifies three modes for constituting female religious authority: 'female agency', 'male invitation' and 'state intervention'. Significantly, the authors problematise the equation of liberal spaces with enabling opportunities and conservative communities or norms with constraining ones: just as male authorities may both encourage and limit female leadership, communities are positioned as both enabling and constraining female leadership.

Nonetheless, this emerging research on female Islamic leadership is often structured around questions relating to the enabling and constraining circumstances that shape the work of female scholars, or around their modes of resistance or accommodation within patriarchal environments or secular-liberal settings. ${ }^{14}$ As a consequence, it tends to over-emphasise the importance that gender equality or equity plays in the lives of these authorities. In Section 2, I similarly explored some of the ways in which female leaders understand the opportunities and constraints that they face in their work. While some stress the barriers they experience vis-à-vis their communities, others suggest that they do not encounter constraints and that the 'individualised' culture of the UK is in fact the main barrier they confront in their work. In Section 3, however, I moved beyond questions of opportunities/constraints,

14 For example, see also Nyhagen (2019); Piela (2013) and (Minganti 2012; Ismah 2016; Maritato 2017). 
resistance/accommodation to argue that female authorities do not necessarily view these questions as important or necessarily relevant. Rather, they are more preoccupied with ensuring that they act as good, pious leaders. Their work and complex subjectivities, therefore, cannot be fully captured by engaging solely with 'strong' theories (Stewart 2008), dominant frameworks around gender equality, authority and legitimacy or reductive binary logics that often dominate scholarly work and public debates on Muslim women.

The female authorities in the UK discussed in this article shift between emphasising gendered forms of authority — by stressing their natural abilities to care, empathise and guide young women —and transcending or pluralising gendered ideals. Like the muqaddamas described by Hill (2018), they draw from within the Islamic tradition and distance themselves from liberal discourses of empowerment. They also do not speak about resisting patriarchal interpretations or forms of authority and do not seek to reinterpret the texts by adopting feminist or human rights analytical tools (e.g., Mir-Hosseini et al. 2015; Wadud 2006). Rather, similarly to the women discussed in the literature on pious self-cultivation (Mahmood 2005; Deeb 2006), their starting point is the Islamic tradition and 'orthodox' interpretations. Their ultimate aim is to act as good, pious leaders rather than to contest male authority or to fight for more spaces for female scholars, although this is often one of the effects of their work. Moreover, in their efforts to pluralise the tradition from within, they complicate and move beyond the oppositions between liberal/orthodox Islam, resistance/accommodation and enabling/constraining contexts that dominate public and academic debate on the topic.

In contrast to the muqaddamas described by Hill (2018), the guidance female authorities in the UK provide is not only spiritual but also practical, and it involves contextualising and applying knowledge in the British context. Their legitimacy is gained not solely through their embodied performances, but also, importantly, through their discourse, argumentation and reasoning. As this article has shown, they apply an Islamic framework to 'think of new possibilities' (Bano 2017, p. 23) in their efforts to guide young female Muslims and their communities towards alternative, Islamic-inspired ways of living that contribute to British society while remaining critical of some of its less desirable dimensions. As a result, their teachings and experiences make space for more female scholars, but most importantly, these authorities imagine and develop new ideas on knowledge, and plural ideals for pious public engagement for Muslim women in Britain. By positioning themselves as natural guides while simultaneously transcending and pluralising their roles by drawing on different aspects of the Islamic tradition, female authorities are making possible diverse ideals and imaginings of what it means to be a publicly engaged Muslim woman in Britain that cannot be subsumed within binaries of enabled/constrained or liberal/orthodox Islam. These ideals expand our understandings of female Muslim subjectivities in Europe (Jouili 2015; Fernando 2014; Jacobsen 2011) and contribute to emerging work on changing forms of Islamic knowledge production in Europe (van Bruinessen and Allievi 2012).

\section{Conclusions}

In making sense of their authority, this new generation of leaders is navigating between claiming a distinctly female form of authority and recognising that they are more than 'just mothers' or 'just females'. These leaders both accept and critique not only the idea of guidance as women's natural role, but also the broader structures of Islamic authority within which their work is situated. Some see themselves through a notion of 'gender equity' (Deeb 2006) in which their work is unique and complementary to that of men. At the same time, some present gender as irrelevant, and others pluralise their roles and critique the ways in which their gendered roles position them in inferior positions within structures of authority and within British society. Through their multiple and fluid understandings of themselves, these leaders are able to reconcile seemingly contradictory notions of gender. The ways in which they make sense of gender, therefore, caution against an uncritical celebration of female religious authorities. While these new authorities might celebrate the new visibility and growth of female scholars, some also recognise that over-emphasising their femininity and gender can mask other aspects of their subjectivities and the varied nature of the work that they do. 
Female authorities are creatively engaging with the Islamic tradition by drawing selectively on different gendered ideals embedded within it and problematising a singular and monolithic notion of 'feminine piety', 'Muslim womanhood' or the necessary relevance of gender in matters of knowledge and spirituality. They draw predominantly from notions and role models taken from the Islamic tradition, but also draw inspiration from national and global discourses on women and leadership and structural critiques of patriarchy and weave these back into the tradition. In doing so, they offer plural visions of pious female forms of leadership that are neither liberal nor feminist, nor viewed as forms of resistance or accommodation, but that are rather based within the Islamic tradition, while reworking it in the British context. They navigate between naturalised ideals of pious motherhood, models from the tradition that de-emphasise motherhood, Sufi notions of transcending gender, and critiques of patriarchal structures of power and of individualistic society in the process of imagining new possibilities and ways of being. Even as they clearly separate themselves from feminist positions and transcend the binary between liberal and orthodox Islam, there is always a risk that by pluralising their activities, they are perceived as 'too liberal' within their communities. Ustadha Iffet's experience points to the way in which this dichotomy-which is circulated by mainstream public discourses on Islam but also within Muslim communities-continues to shape representations of female Islamic authorities in the UK and to flatten the nuances and complexities of their work.

Female authorities are not only transforming ideals of pious leadership, but also contributing to the development of new, multiple forms of knowledge in the European context. Through their guidance work, these female authorities join recent efforts to develop a European Islam (Ramadan 2004; Caeiro 2010; Bowen 2009, 2016). New generations of Islamic scholars in Europe, trained in the traditional Islamic sciences, are recognising the need to adapt and contextualise knowledge in the European context by bringing Islamic theology into conversation with secular forms of knowledge and addressing the lived realities and everyday struggles experienced by Muslims in the West (Lewis and Hamid 2018; Scott-Baumann and Cheruvallil-Contractor 2015). While these transformations similarly apply to the work of male and female scholars, they have largely been explored in the literature through the lens of male scholars and imams or the work of large, male-dominated institutions such as the Sharia Councils or European Council of Fatwa and Research (ECFR). As a consequence, juristic authority has also tended to dominate these accounts, reflecting broader public perceptions about dominant forms of Islamic authority (Kloos and Kunkler 2016). Recent research has shown, however, how young Muslims are more likely to approach individual scholars and teachers for advice and guidance with everyday problems rather than attend or consult large institutions such as the Sharia councils or seek a fatwa from a local mufti (Qureshi 2016, pp. 179-81).

Focusing on the varied and fluid nature of the guidance work of female authorities, therefore, highlights the importance of different forms of knowledge, authority and pious public engagement. It points to the increasing relevance of providing more than just legal judgments or fatwas by offering holistic, personal and collective guidance that blurs the lines between figh advice, spiritual guidance and counseling, and is based on trusting, intimate, empathic and less hierarchical relations with Muslim communities. Female authorities are developing new understandings of Islamic leadership as a form of care that is both for individuals and potentially transformative of society at large.

Funding: This research was funded by a Leverhulme Trust Early Career Fellowship.

Acknowledgments: I cannot express my gratitude enough to all the female Islamic authorities who took the time to meet with me and invited me to their many classes, events and retreats over the last few years. Their personal journeys are inspirational, and I continue to learn so much from them. I am also very grateful to Sophie Gilliat-Ray and Riyaz Timol, the editors of this Special Issue, for inviting me to their conference in Cardiff on Leadership, Authority and Representation in British Muslim Communities, and for offering advice on an earlier draft and support throughout the writing process. I also extend my thanks to the two anonymous reviewers, the editorial team at Religions and Kay Celtel for copy-editing the manuscript. I am particularly indebted to Sertaç Sehlikoglu and Zainab Kabba for their invaluable feedback and encouragement on earlier drafts.

Conflicts of Interest: The author declares no conflict of interest. 


\section{References}

Asad, Talal. 1986. The Idea of the Anthropology of Islam. Washington, DC: Center for Contemporary Arab Studies.

Bano, Masooda. 2017. Female Islamic Education Movements: The Re-Democratisation of Islamic Knowledge. Cambridge: Cambridge University Press.

Bano, Masooda, and Hilary Kalmbach, eds. 2012. Women, Leadership, and Mosques: Changes in Contemporary Islamic Authority. Leiden: Brill.

Bowen, John R. 2009. Can Islam Be French? Pluralism and Pragmatism in a Pluralist State. Princeton: Princeton University Press.

Bowen, John R. 2016. On British Islam: Religion, Law, and Everyday Practice in Shari'a Councils. Princeton: Princeton University Press.

Caeiro, Alexandre. 2010. The Power of European Fatwas: The Minority Figh Project and the Making of an Islamic Counterpublic. International Journal of Middle East Studies 42: 435-49. [CrossRef]

Cheruvallil-Contractor, Sariya. 2016. Motherhood Motherhood as Constructed by Us: Muslim Women's Negotiations from a Space That Is Their Own. Religion and Gender 6: 9-28. [CrossRef]

Deeb, Lara. 2006. An Enchanted Modern: Gender and Public Piety in Shi'I Lebanon. Princeton: Princeton University Press. Ewing, Katherine P. 2008. Stolen Honor: Stigmatizing Muslim Men in Berlin. Stanford: Stanford University Press.

Fernando, Mayanthi L. 2014. The Republic Unsettled: Muslim French and the Contradictions of Secularism. Durham: Duke University Press.

Gilliat-Ray, Sophie, Muhammad Mansur Ali, and Stephen Pattison. 2013. Understanding Muslim Chaplaincy. Farnham: Ashgate.

Hammer, Juliane, and Riem Spielhaus. 2013. Muslim Women and the Challenge of Authority: An Introduction. Special Issue of the Muslim World 103: 287-94. [CrossRef]

Hill, Joseph. 2018. Wrapping Authority: Women Muslim Leaders in a Sufi Movement in Dakar, Senegal. Toronto: Toronto University Press.

Ismah, Nor. 2016. Destabilising Male Domination: Building Community-Based Authority among Indonesian Female Ulama. Asian Studies Review 40: 491-509. [CrossRef]

Jacobsen, Christine M. 2011. Islamic Traditions and Muslim Youth in Norway. Leiden: Brill.

Jouili, Jeanette S. 2015. Pious Practice and Secular Constraints: Women in the Islamic Revival in Europe. Stanford: Stanford University Press.

Jouili, Jeanette S., and Schirin Amir-Moazami. 2006. Knowledge, Empowerment, and Religious Authority among Pious Muslim women in France and Germany. The Muslim World 96: 617-42. [CrossRef]

Kalmbach, Hilary. 2012. Introduction: Islamic Authority and the Study of Female Religious Leaders. In Women, Leadership, and Mosques: Changes in Contemporary Islamic Authority. Edited by Masooda Bano and Hilary Kalmbach. Leiden: Brill, pp. 1-30.

Kloos, David, and Mirjam Kunkler. 2016. Studying Female Islamic Authority: From Top-down to Bottom-up Modes of Certification. Asian Studies Review 40: 479-90. [CrossRef]

Lewis, Philip, and Sadek Hamid. 2018. British Muslims: New Directions in Islamic Thought, Creativity and Activism. Edinburgh: Edinburgh University Press.

Liberatore, Giulia. 2017. Somali, Muslim, British: Striving in Securitized Britain. London: Bloomsbury.

Mahmood, Saba. 2005. Politics of Piety: The Islamic Revival and the Feminist Subject. Chicago: University of Chicago Press.

Maritato, Chiara. 2017. Compliance or Negotiation? Diyanet's Female Preachers and the Diffusion of a 'True' Religion in Turkey. Social Compass 64: 530-45. [CrossRef]

Minganti, Pia K. 2012. Challenging from Within: Youth Associations and Female Leadership in Swedish Mosques. In Women, Leadership, and Mosques: Changes in Contemporary Islamic Authority. Edited by Masooda Bano and Hilary Kalmbach. Leiden: Brill, pp. 371-91.

Mir-Hosseini, Ziba, Mulki Al-Sharmani, and Jana Rumminger. 2015. Men in Charge? Rethinking Authority in Muslim Legal Tradition. London: Oneworld Publications.

Moore, Henrietta L. 2011. Still Life. Hopes, Desires and Satisfactions. Cambridge: Polity Press.

Nyhagen, Line. 2019. Mosques as Gendered Spaces: The Complexity of Women's Compliance with, and Resistance to, Dominant Gender Norms, and the Importance of Male Allies. Religions 10: 321. [CrossRef] 
Omar, Sara. 2013. Al-Qubaysiyyat: Negotiating Female Religious Authority in Damascus. The Muslim World 103: 347-62. [CrossRef]

Petersen, Jesper. 2019. Media and the Female Imam. Religions 10: 159. [CrossRef]

Piela, Anna. 2013. “Women are Believers in Their Own Right": One Muslim Woman's Challenge to Dominant Discourses Shaping Gender Relations in Islam. The Muslim World 103: 389-403. [CrossRef]

Qureshi, Kaveri. 2016. Marital Breakdown among British Asians Conjugality, Legal Pluralism and New Kinship. London: Palgrave Macmillian.

Ramadan, Tariq. 2004. Western Muslims and the Future of Islam. Oxford: Oxford University Press.

Scott-Baumann, Alison, and Sariya Cheruvallil-Contractor. 2015. Islamic Education in Britain: New Pluralist Paradigms. London and New York: Bloomsbury Academic.

Sehlikoglu, Sertaç. 2018. Revisited: Muslim Women's Agency and Feminist Anthropology of the Middle East. Contemporary Islam 11: 73-92. [CrossRef]

Sehlikoglu, Sertaç. Forthcoming. Working out Desire: Women, Sport and Self-Making in Istanbul. Syracuse: Syracuse University Press.

Spielhaus, Riem. 2012. Making Islam Relevant: Female Authority and Representation of Islam in Germany. In Women, Leadership, and Mosques: Changes in Contemporary Islamic Authority. Edited by Masooda Bano and Hilary Kalmbach. Leiden: Brill, pp. 437-56.

Stewart, Katheleen. 2008. Weak Theory in an Unfinished World. Journal of Folklore Research 45: 71-82. [CrossRef] van Bruinessen, Martin, and Stefano Allievi, eds. 2012. Producing Islamic Knowledge, Transmission and Dissemination in Western Europe. London: Routledge.

Wadud, Amina. 2006. Inside the Gender Jihad: Women's Reform in Islam. Oxford: Oneworld Publications.

(C) 2019 by the author. Licensee MDPI, Basel, Switzerland. This article is an open access article distributed under the terms and conditions of the Creative Commons Attribution (CC BY) license (http://creativecommons.org/licenses/by/4.0/). 